\title{
Bio-Particulates in Atmosphere - A Brief Review
}

\author{
Shah Ishfaq ${ }^{1}$, Syeed Mudasir ${ }^{2}$, Ajaz Rasool $^{3}$ and Baba Uqab ${ }^{1 *}$ \\ ${ }^{1}$ Department of Environmental Science, University of Kashmir, Srinagar, J\&K, India \\ ${ }^{2}$ Department of Higher Education J\&K, Abdul Ahad Azad Memorial Degree College \\ Bemina, India \\ ${ }^{3}$ Department of Zoology, University of Kashmir, Srinagar, J\&K, India \\ *Corresponding Author: Baba Uqab, Department of Environmental Science, University \\ of Kashmir, Srinagar, J\&K, India.
}

\begin{abstract}
Bioaerosols encompassing viruses, bacterial cells, protozoa and their cysts, fungal cells, pollen grains and toxic spores from these organisms pose direct threat to human health. Epidemics like Severe Acute respiratory Syndrome and Middle East Respiratory syndrome are reported to be caused by aerosols. In this brief review we have provide detailed description of various bioaersol agents, their role and affects on human health like COPD, Bronchites etc.
\end{abstract}

Keywords: Bioaerosols; Bioparticulates; Endotoxins; Biofragments

\section{Introduction}

Bio-particulates or bioaerosols comprise of particulates of biological origin in size range of approximately 0.02 to $100 \mu \mathrm{m}$. It encompasses viruses, intact bacterial cells, protozoa and their cysts, fungal cells and plant pollen grains and spores. These agents are responsible for evoking responses like hypersensitivity, irritations and inflammation in addition to infectious diseases $[1,2]$. The exposure to the bioaerosols has been reported to cause severe outbreaks like severe acute respiratory syndrome (SARS) [3], the H1N1 flu [4] and Middle East respiratory syndrome (MERS) [5] etc. There has been a well-established study on relationship between exposure to bioaerosols and their health impacts [6,7]. Various government and private organisations have set standards and guidelines for bioaerosol limits (Table 1) [8]. Usually whole microorganism are responsible to cause infections, but allergic reactions can be caused by microbial fragments or by products [9] like endotoxins and $\beta-(1-3)-D-g l u c a n s$ [10]; microbial VOCs [11] and mycotoxins [12]. Besides impact on health, these also serve as nuclei for cloud formation and atmospheric nuclei [13]. Organic acids present in the atmospheric cloud are utilised by certain bacterial cells to carry their metabolism [6]. There are a variety of factors responsible for differences in indoor as well as outdoor bioaerosol composition. For outdoor environments geographic location, meteorological parameters, population density and vegetation cover are main factors while for indoor environments the factors include dust resuspension, kitchen activities, plants internal air characteristics and air conditioning [14-16]. The dust events over continents carry large pulses of microbes and biogenic particles
Received: February 24, 2020

Published: March 20, 2020

(C) All rights are reserved by Baba Uqab., et al. 


\begin{tabular}{|c|c|c|c|}
\hline Organization & Guideline & Remarks & Reference \\
\hline \multirow{3}{*}{$\begin{array}{l}\text { American Conference of Governmental Indus- } \\
\text { trial Hygienists (ACGIH) }\end{array}$} & $<100 \mathrm{CFU} / \mathrm{m}^{3}$ & Low & \multirow[t]{3}{*}[21]{} \\
\hline & $100-1000 \mathrm{CFU} / \mathrm{m}^{3}$ & Intermediate & \\
\hline & $>1000 \mathrm{CFU} / \mathrm{m}^{3}$ & High & \\
\hline American Industrial Hygiene Association (AIHA) & \multicolumn{2}{|c|}{ There is no safe level of an uncontained pathogenic organism } & {$[22]$} \\
\hline \multirow{6}{*}{$\begin{array}{l}\text { Commission of the European } \\
\text { Communities (CEC) }\end{array}$} & \multicolumn{2}{|r|}{ For houses } & \multirow[t]{6}{*}[23]{} \\
\hline & $<50 \mathrm{CFU} / \mathrm{m}^{3}$ & Very Low & \\
\hline & $<200 \mathrm{CFU} / \mathrm{m}^{3}$ & Low & \\
\hline & $<10^{3} \mathrm{CFU} / \mathrm{m}^{3}$ & Intermediate & \\
\hline & $<10^{4} \mathrm{CFU} / \mathrm{m}^{3}$ & High & \\
\hline & $>10^{4} \mathrm{CFU} / \mathrm{m}^{3}$ & Very High & \\
\hline Healthy Buildings International & $<750 \mathrm{CFU} / \mathrm{m}^{3}$ & $\begin{array}{c}\text { Total airborne bacteria and fungi is OK if species } \\
\text { are not infective or allergenic }\end{array}$ & {$[24]$} \\
\hline \multirow[t]{2}{*}{ Indoor Air Quality Association (IAQ) } & $<300$ & Common fungi is $\mathrm{OK}$ & \multirow[t]{2}{*}[25]{} \\
\hline & $<150$ & $\begin{array}{l}\text { Mixed fungi other than pathogenic orexigenic } \\
\text { is OK }\end{array}$ & \\
\hline \multirow[t]{2}{*}{ IAQ in office buildings: a technical guide } & $>50$ & One species should be investigated & \multirow[t]{2}{*}[26]{} \\
\hline & $<150$ & If mixture of species is $\mathrm{OK}$ & \\
\hline \multirow{2}{*}{$\begin{array}{l}\text { The Netherlands/research methods in biological } \\
\text { indoor air pollution }\end{array}$} & $>104$ & Total fungi is a threat to health & \multirow[t]{2}{*}[27]{} \\
\hline & $>500$ & $\begin{array}{l}\text { One species of potentially pathogenic nature is a } \\
\text { threat to health }\end{array}$ & \\
\hline \multirow{2}{*}{$\begin{array}{l}\text { Occupational Safety and Health Administration } \\
\text { (OSHAA) }\end{array}$} & $>1000$ & Indicates contamination & \multirow[t]{2}{*}[28]{} \\
\hline & $\begin{array}{l}>106 \text { fungi/g of } \\
\text { dust }\end{array}$ & Indicates contamination & \\
\hline \multirow[t]{4}{*}{ Environment Canada (EC) } & $\begin{array}{l}\text { Pathogenic and } \\
\text { toxigenic fungi }\end{array}$ & Unacceptable in Indoor air & \multirow[t]{4}{*}[29]{} \\
\hline & $>50 \mathrm{CFU}$ & One species should be investigated & \\
\hline & $<150$ & OK If mixture of species & \\
\hline & $<500$ & $\begin{array}{l}\text { OK if Cladosporium or other common phyllo- } \\
\text { plane }\end{array}$ & \\
\hline Ministry of environment (ME), Republic of Korea & $<800$ & OK & {$[30]$} \\
\hline СРCB/ MOEFCCC India & \multicolumn{3}{|c|}{ No standard set for Bioaerosols } \\
\hline
\end{tabular}

Table 1: Quantitative standards and guidelines for bioaerosols in air by governmental and private organizations (Kim., et al. 2018 with some modifications).

cumulated in the lungs evoking an immune response [37]. Concentration of aerosols usually vary with seasons. Fungi were found up to the concentration of $177 \mathrm{CFU} / \mathrm{m}^{3}$ during winter [38] whereas during summer it increased to $357 \mathrm{CFU} / \mathrm{m}^{3}$ in summer [39]. This variation may be due to the availability of optimum conditions for bioaerosols to multiply and survive in summers. Similar seasonal variation was observed by Thorne., et al. (1992) [40] while studying the bacterial bioerosol in waste water treatment facility. In addition to meteorological parameters the higher number of bacteria in air during summer is attributable to abundant vegetation cover providing sufficient dwelling place for bacteria $[41,42]$. In the indoor environment the concentration of bacteria in addition to outdoor concentrations depend on the number of inhabitants, their activities and insufficient ventilation [43].

\section{Viruses}

Viruses are the particles that multiply when present in a living tissue or cell. Although they are present in non living environment these may pose a public health threat because of unstable genetic composition mutating to unexpected virulent forms. Unlike bacteria and fungi, viruses need a host to replicate as well as show an impact. There have been sparse evidences relating the presence of viruses in aerosols. Studies carried on the outbreak of viral events like MERS in 2012 took place due to transmission of infectious aerosolized particles via airborne route of exposure primarily over close contact [44]. The rate under hospital set ups have been reported to be $1.1-10 \%[45,46]$. Same may be attributed to the previous SARS-CoV outbreak and recent $2019 \mathrm{nCoV}$ outbreak in Wu- 
han China which became a global medical emergency within short period of time leaving more than 3000 dead worldwide [47]. The viruses may spread through fomite contacts as well, but studies reveal that the fomite exposures were not significant in outbreak of coronaviruses [48]. The symptoms to exposure of viruses depend on the type of virus that enters the body. But the entry of viruses through airborne route targets the respiratory tract as the first target. For example the coronavirus infections are characterised by Sore throat, Nausea, diarrhoea, shortness of breath and pneumonia and death [49]. The study of presence and transmission through airborne route need more studies to be carried.

\section{Endotoxins}

Endotoxins are the lipopolysaccharides present as a vital structural component of membranes of gram negative bacteria [50]. Airborne endotoxins are significantly associated with fine particulate matter [51]. Fine and ultra fine particulate matter is not only a dust particle but a mixture of elements of crustal origin, metals, PAHs and biologically active endotoxins that are easily deposited in the alveoli and small airways [52]. In combination with other airborne agents like bacteria, fungi and viruses, endotoxins increase the severity of immune response leading to adverse health effects [53]. However, only a few studies have reported the airborne concentration of endotoxins [54] especially regarding continuous observations [51]. Exposure to endotoxins prompt and aggravate wheezing in children as well as adults [54], impaired lung function [56] COPD [57], acute inflamatory response with increase in blood cytokine levels like neutrophils, interleukin-6 etc [58,59].

\section{Discussion and Conclusions}

Bioparticulates or bioaerosols are associated with the particulate matter as bacteria, fungi, viruses, spores and their biofragments like endotoxins. These constitute the biological component of the atmosphere and pose serious health problems on inhalation having an immediate impact on respiratory system. Exposure to these components may cause serious illnesses like COPD, Bronchites and may even sometimes result in serious outbreaks especially, in case of viruses. Although research is going on their presence in aerosolised form, extensive studies are required to be carried to understand their role in climate change and impact on biosphere as a whole.

\section{Bibliography}

1. Balmes JR and Scannell DH. "Occupational lung diseases, in Occupational and Environmental Medicine, $2^{\text {nd }}$ edition., LaDou, J., Ed., Appleton and Lange, Stamford (1997): 20.

2. Douwes J., et al. "Bioaerosol health effects and exposure assessment: progress and prospects". The Annals of Occupational Hygiene 47.3 (2003): 187-200.
3. Ksiazek TG., et al. "A novel coronavirus associated with severe acute respiratory syndrome". New England Journal of Medicine 348.20 (2003): 1953-1966.

4. Bautista E., et al. "Writing Committee of the WHO Consultation on Clinical Aspects of Pandemic (H1N1) 2009 Influenza. Clinical aspects of pandemic 2009 influenza A (H1N1) virus infection". The New England Journal of Medicine 362.18 (2010): 1708-1719.

5. Zumla A., et al. "Middle East respiratory syndrome". The Lancet 386.9997 (2015): 995-1007.

6. Bowers RM., et al. "Seasonal variability in airborne bacterial communities at a high-elevation site". Atmospheric Environment 50 (2012): 41-49.

7. Chow J C., et al. "Characterization of ambient PM10 bioaerosols in a California agricultural town". Aerosol and Air Quality Research 15.4 (2015): 1433-1447.

8. Kim K., et al. "Airborne bioaerosols and their impact on human health". Journal of Environmental Sciences 67 (2018): 23-35.

9. Burrell Robert. "Microbiological agents as health risks in indoor air". Environmental Health Perspectives 95 (1991): 29-34.

10. Bioaerosols ACGIH. "Bioaerosols assessment and control". In American Conference of Governmental Industrial Hygienists, Cincinnati, Ohio (1999).

11. Miller DJ. "Fungi as contaminants in indoor air". Atmospheric Environment 26A (1992): 2163-2172.

12. Robbins CA., et al. "Health effects of mycotoxin in indoor air: a critical review". Appl Occupational and Environmental Hygiene 15 (2000): 773-784.

13. Mohler 0., et al. "Microbiology and atmospheric processes: the role of biological particles in cloud physics". Biogeosciences 4 (2007): 2559-2591.

14. Mehta YB., et al. "Tsukamurella infection: a rare cause of community-acquired pneumonia". The American Journal of the Medical Sciences 341.6 (2011): 500-503.

15. Nasir ZA., et al. "Bioaerosols in residential micro-environments in low income countries: A case study from Pakistan". Environmental Pollution 168 (2012): 15-22.

16. Ruzer LS and Harley NH. "Aerosols Handbook: Measurement, Dosimetry, and Health Effects". CRC Press (2012). 
17. Burrows SM., et al. "Bacteria in the global atmosphere - Part 1: Review and synthesis of literature data for different ecosystems". Atmospheric Chemistry and Physics 9 (2009): 92639280.

18. Jaenicke R., et al. "Omnipresence of biological material in the atmosphere". Environ Chemical 4 (2007): 217.

19. Graham B., et al. "Composition and diurnal variability of the natural Amazonian aerosol". Journal of Geophysical Research 108 (2003): 47645.

20. Matthias-Maser S and Jaenicke R. "The size distribution of primary biological aerosol particles with radii $>0.2 \mu \mathrm{m}$ in an urban/ rural influenced region". Atmospheric Research 39 (1995): 279-286.

21. Macher JM., et al. "Sampling airborne microorganisms and aeroallergens”. In: Cohen, B.S., Hering, S.V. (Eds.), Air Sampling Instruments for Evaluation of Atmospheric Contaminants, 8th edition ACGIH, Cincinnati, Ohio, USA (1995): 589-617.

22. AIHA (American Industrial Hygiene Association), "Biosafety Committee Biohazards Reference Manual”. AIHA, Washington DC, USA (1986).

23. CEC (Commission of the European Communities). Report No. 12: Biological Particles in Indoor Environments: Luxembourg (1994).

24. Rao CY., et al. "Review of quantitative standards and guidelines for fungi in indoor air". Journal of the Air and Waste Management Association 46 (1996): 899-908.

25. IAQA. (Indoor Air Quality Association). Indoor Air Quality Association Inc. Indoor Air Quality Standard \#95-1 Recommended for Florida. Indoor Air Quality Association, Inc., Longwood, Florida, USA (1995).

26. Malmberg P. "Microorganisms". In: Beije, B., Lundberg, P. (Eds.), Criteria Documents from the Expert Group. Arbets Milio Institutet, Solna, Sweden (1991).

27. Heida H., et al. "Occupational exposure and indoor air quality monitoring in a composting facility". American Industrial Hygiene Association 56 (1995): 39-43.

28. OSHA (Occupational Safety and Health Administration). "Indoor air quality-proposed rule" notice of proposed rulemaking”. Federal Register 59.65 (1994): 15968-16039.

29. EC (Environment Canada). Exposure Guidelines for Residential Indoor Air Quality, Environment Canada. Federal-Provincial Advisory Committee on Environmental and Occupational Health, Ottawa, Ontario 23 (1989)
30. Ministry of Environment, Republic of Korea (2010).

31. Smith DJ., et al. "Airborne bacteria in earth's lower stratosphere resemble taxa detected in the troposphere: results from a new NASA Aircraft Bioaerosol Collector (ABC)". Frontiers in Microbiology (2018).

32. Aylor DE., et al. "Tracking the potato late blight pathogen in the atmosphere using unmanned aerial vehicles and Lagrangian modeling". Agricultural and Forest Meteorology 151.2 (2011): 251-260.

33. Jones AM and Harrison RM. "The effects of meteorological factors on atmospheric bioaerosol concentrations - a review". Science of the Total Environment 326 (2004): 151-180.

34. Bovallius A., et al. "Long-range air transmission of bacteria". Applied and Environmental Microbiology 35 (1978) 12311232.

35. Prospero J., et al. "Interhemispheric transport of viable fungi and bacteria from Africa to the Caribbean with soil dust". Aerobiologia 21 (2005): 1-19.

36. Margarit XT., et al. "Bioaerosols in the Barcelona subway system". Indoor Air John Wiley and Sons (2016).

37. Buskirk AD., et al. "A murine inhalation model to characterize pulmonary exposure to dry Aspergillus fumigatus conidia". PLoS One 9 (2014): e109855.

38. Lee BU., et al. "Concentration of culturable bioaerosols during winter". Journal of Aerosol Science 94 (2016): 1-8.

39. Heo KJ., et al. "Concentration of environmental fungal and bacterial bioaerosols during the monsoon season". Journal of Aerosol Science 77 (2014): 31-37.

40. Thorne PS., et al. "Comparison of bioaerosol sampling methods in barns housing swine". Applied and Environmental Microbiology 58 (1992): 2543-2551.

41. Amato P., et al. "An important oceanic source of micro-organisms for cloud water at the Puy de D^ome (France)". Atmospheric Environment 41 (2007): 8253-8263.

42. Tong Y and Lighthart B. "The annual bacterial particle concentration and size distribution in the ambient atmosphere in a rural area of the Willamette valley, Oregon". Aerosol Science and Technology 32 (2000): 393-403.

43. Yoon C., et al. "Indoor air quality differences between urban and rural preschools in Korea". Environmental Science and Pollution Research 18.3 (2011): 333-345. 
44. Xia S., et al. "Middle East respiratory syndrome coronavirus (MERSCoV) entry inhibitors targeting spike protein". Virus Research 194 (2014): 200-210.

45. Al-Abdallar M. "Hospital-associated outbreak of Middle East respiratory syndrome coronavirus: A serologic, epidemiologic, and clinical description". Clinical Infectious Diseases 59.9 (2014): 1-9.

46. Al-Tawfiq JA and Perl TM. "Middle East respiratory syndrome coronavirus in healthcare settings". Current Opinion in Infectious Diseases 28.4 (2015): 392-396.

47. WHO. Coronavirus disease 2019 (COVID-19) situation report (2020).

48. Xiao S., et al. "A study of the probable transmission routes of MERS-CoV during the first hospital outbreak in the Republic of Korea". Indoor Air 28.1 (2018): 51-63.

49. Banik GR., et al. "Middle East respiratory syndrome coronavirus "MERS-CoV": Current knowledge gaps". Paediatric Respiratory Reviews 16.3 (2015): 197-202.

50. Beutler B and Rietschel ET. "Innate immune sensing and its roots: the story of endotoxin". Nature Reviews Immunology 3.2 (2003):169-176.

51. Tage IB., et al. "Temporal and spatial patterns of ambient endotoxin concentrations in Fresno, California". Environmental Health Perspectives 118.10 (2010): 1490-1496.

52. Kreyling WG., et al. "Anatomic localization of 24- and 96-h particle retention in canine airways". Journal of Applied Physiology 87 (1999): 269-284.

53. Degobbi C and Hila P. "Endotoxin as modifier of particulate matter toxicity: a review of the literature". Aerobiologia 27 (2011): 97-105.

54. Cheng JYW., et al. "Bioactive and total endotoxins in atmospheric aerosols in the Pearl River Delta region, China". Atmospheric Environment 47 (2012): 3-11.

55. Abbing-Karahagopian V., et al. "Effect of endotoxin and allergens on neonatal lung function and infancy respiratory symptoms and eczema". Pediatric Allergy and Immunology 23.5 (2012): 448-455.

56. Liebers V., et al. "Health effects due to endotoxin inhalation (review)". Archives of Toxicology 82.4 (2008): 203-210.
57. Schwartz DA., et al. "Determinants of longitudinal changes in spirometric function among swine confinement operators and farmers". American Journal of Respiratory and Critical Care Medicine 151.1 (1995): 47-53.

58. Doyen V., et al. "Time course of endotoxininduced airways' inflammation in healthy subjects". Inflammation 35.1 (2012): 12-17.

59. Moller W., et al. "Differential inflammatory response to inhaled lipopolysaccharide targeted either to the airways or the alveoli in man". PLoS One 7.4 (2012): 33505.

\section{Assets from publication with us}

- Prompt Acknowledgement after receiving the article

- Thorough Double blinded peer review

- Rapid Publication

- Issue of Publication Certificate

- High visibility of your Published work

Website: https://www.actascientific.com/

Submit Article: https://www.actascientific.com/submission.php Email us: editor@actascientific.com

Contact us: +919182824667 